\title{
Design of heat exchanger for the production of zinc imidazole framework-8 (ZIF-8) particles
}

DOI:10.36909/jer.ASSEEE.16035

Asep Bayu Dani Nandiyanto ${ }^{1, *}$, Risti Ragadhita ${ }^{1}$, Silmi Ridwan Putri ${ }^{1}$, Rina Maryanti ${ }^{2}$, Teguh Kurniawan $^{3}$

${ }^{1}$ Departemen Kimia, Universitas Pendidikan Indonesia, Bandung, Indonesia.

${ }^{2}$ Departemen Pendidikan Khusus, Universitas Pendidikan Indonesia, Bandung, Indonesia.

${ }^{3}$ Departemen Teknik Kimia, Universitas Sultan Ageng Tirtayasa, Serang, Indonesia

*Email: nandiyanto@upi.edu; Corresponding Author.

\begin{abstract}
The design of a heat exchanger is very effective to reduce total production costs, compared to buying a ready-made exchanger. This study aims to design a heat exchanger with a manual calculation analysis method to get dimension calculations of the heat exchanger. Dimension calculation of heat exchanger aims to determine the quality of the heat exchanger based on the overall heat transfer coefficient and the dirt factor that occurs in the heat exchanger. The designed heat exchanger is a shell and tube type with 1 (one) pass shell and 2 (two) pass tubes using water as hot fluid and cold fluid. The fluid flow is assumed to be the opposite. The results show the effectiveness of the heat exchanger reaches more than $50 \%$. The performance of the designed heat exchanger is relatively good but it still does not meet the minimum requirements of the established dirt factor. This research can be useful as a learning method regarding the design process, working mechanism, and heat exchanger performance.
\end{abstract}

Keywords: Dimensions, heat exchanger, Performance 


\section{INTRODUCTION}

The heat exchanger is a crucial apparatus in the industry. This apparatus relates to industrial heating and cooling, as well as heat recovery processes (Chen et al., 2019). The process of heat exchange between fluids occurs through conductive elements (Dekhil et al., 2020). This process happens by utilizing the process of heat transfer from high- to low-temperature fluid (Shahsavar et al., 2021).

The heat exchanger is widely utilized in the oil and gas processing industry. Currently, almost all existing chemical industries utilize heat exchangers (Dekhil et al., 2020). Therefore, the heat exchanger in industrial processes is almost always customized and designed. Numerous different heat exchanger designs are commercially available to meet superior conditions. Indeed, the design development must provide accommodations for a wide variety of substances that mix frequently, and often with uncertain compositions and properties to handle.

In large-scale industries, heat exchanger works well to reduce fuel consumption, saving millions of dollars in annual production costs (Araiz et al., 2020). Given the importance of heat exchangers in the industrial sector, the design of heat exchangers in the industry is inevitable, especially for ZIF-8 industry production due to the involvement of hot water in the ZIF-8 production industry. The heat will be released into the environment and is usually wasted without being used. It should be noted that heat waste that is disposed of directly without being processed has a negative impact on the environment which can cause thermal pollution (Delpech et al., 2018).

Based on our previous studies on the design of industrial apparatus (Nandiyanto et al., 2018; Sukmafitri et al., 2020), the purpose of this study is to propose a design of a heat exchanger 
that is used to utilize heat energy from waste hot water produced from the production of zinc imidazole framework-8 (ZIF-8) particles in the industry. ZIF-8 is one of the metal-organic framework materials. In the ZIF-8 process, the heat exchanger aims to reheat the water using the concept of utilizing thermal energy from the hot water waste. In short, the temperature of the hot water waste can be decreased and then can be discharged into the environment or river without endangering the ecosystem in the river (Delpech et al., 2018). Figure 1 shows an illustration of the production of ZIF-8.

This study designed a heat exchanger with a manual calculation analysis method to get dimension calculations of shell and tube type of heat exchanger. Dimension design of heat exchanger aims to determine the quality of the heat exchanger based on the overall heat transfer coefficient and the fouling factor that occurs in the heat exchanger. The shell and tube typed heat exchanger is designed simply but still refers to the existing design rules. This study can be useful as a learning method regarding the design process, working mechanism, and understanding the performance of the heat exchanger.

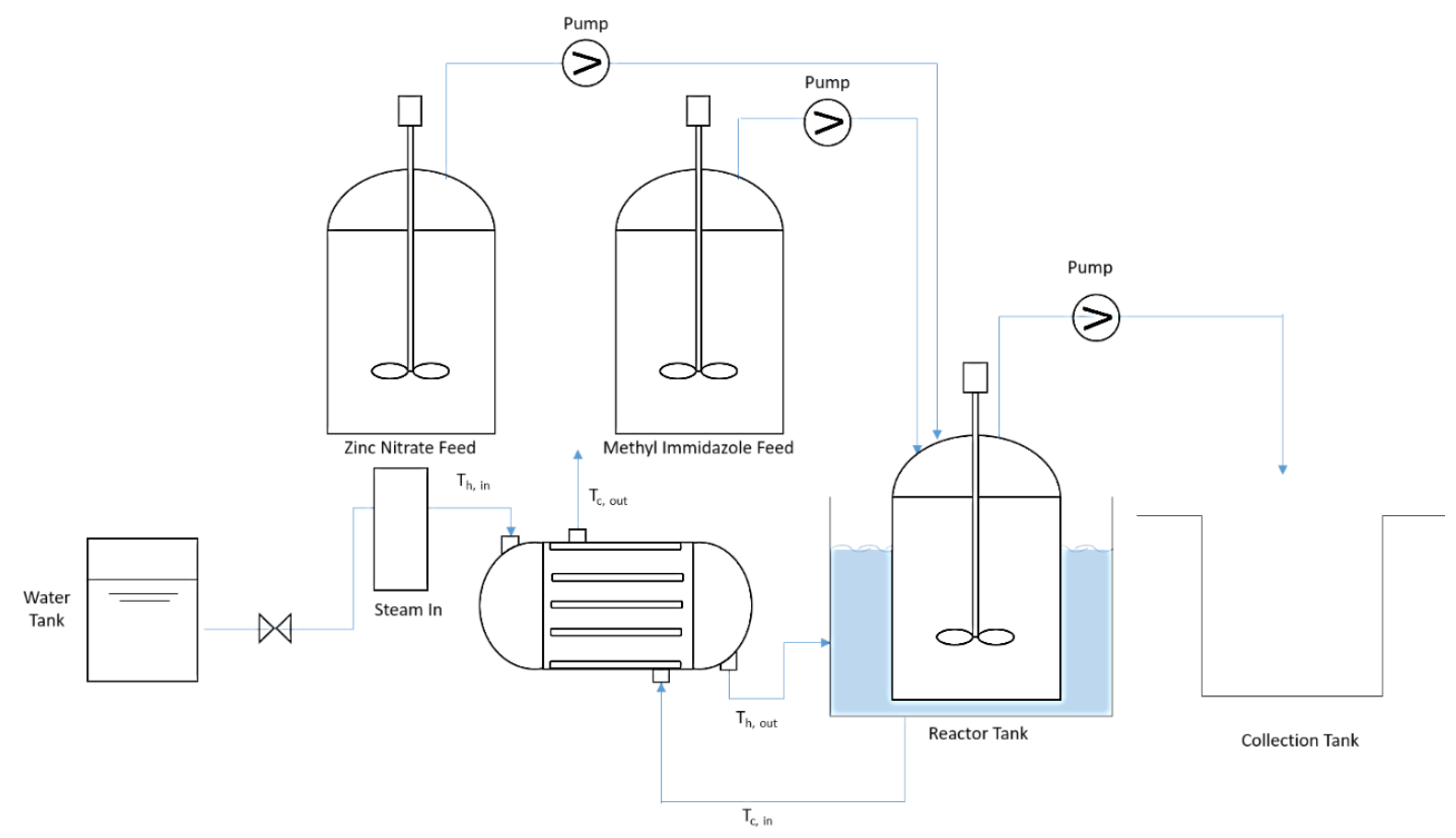

FIGURE 1 Illustration of ZIF-8 Particles Production 


\section{MATERIAL AND METHOD}

This study designed a heat exchanger for application in the production of ZIF-8 particles. The heat exchanger design is a shell and tube type heat exchanger with 1 (one) pass shell and 2 (two) pass tubes using water as hot and cold fluids. The design specification of the heat exchanger was calculated using Microsoft Excel with consideration of several parameters (Nurahmadi, 2017 \& Ihsan, 2017). Meanwhile, the results of drawings and layouts of the designed heat exchanger apparatus were carried out using the HRTI application that has been calculated manually. Here, the performance calculations of the heat exchanger were focused based on a calculation using the formula in equations 1-5 to determine the thermal load $(Q)$, the logarithmic mean temperature difference $(L M T D)$, the heat transfer surface area $(A)$, and the number of tubes $(N t)$, sequentially.

Based on the conservation of energy, the amount of heat transfer from the hot fluid to the cold fluid (thermal load, $Q$ ) can be calculated by equations 1 and 2 .

$Q_{\text {in }}=Q_{\text {out }}$

$m_{c} \times C p_{c} \times \Delta T_{c}=m_{h} \times C p_{h} \times \Delta T_{h}$

where $Q$ is the energy transferred (W), $m$ is the mass flow rate of the fluid $(\mathrm{kg} / \mathrm{s}), C p$ is the specific heat, dan $\Delta T$ is the fluid temperature difference $\left({ }^{\circ} \mathrm{C}\right)$.

The temperature of the fluid in a heat exchanger is usually not constant but differs from point to point as heat flows. Therefore, the thermal resistance is constant, the heat flow rate will be different along the path of the heat exchanger. Determination of the logarithmic mean temperature difference (LMTD) is calculated by equation 3 .

$L M T D=\frac{\left(T_{h i}-T c_{i}\right)-\left(T_{h o}-T c_{o}\right)}{\ln \frac{\left(T_{h i}-T c_{i}\right)}{\left(T_{h o}-T c_{o}\right)}}$

where $T_{h i}, T_{h o}, T c_{i}$, and $T c_{o}$ are the temperature of the hot fluid inlet $\left({ }^{\circ} \mathrm{C}\right)$, hot fluid outlet $\left({ }^{\circ} \mathrm{C}\right)$, cold fluid inlet $\left({ }^{\circ} \mathrm{C}\right)$, cold fluid outlet $\left({ }^{\circ} \mathrm{C}\right)$, respectively. 
The design of the heat transfer area $(A)$ can be calculated by equation 4 .

$A=\frac{Q}{U \times L T M D}$

where $Q$ is the energy transferred $(\mathrm{W}), U$ is the overall heat transfer coefficient, and LMTD is the logarithmic mean temperature difference. The $U$ value is obtained from the literature that if the hot fluid contains water and the cold fluid contains water, then the $U$ value is 1000 $\left(\mathrm{W} / \mathrm{m}^{2 \circ} \mathrm{C}\right)$.

The number of tubes $(N t)$ is calculated by equation 5 .

$N t=\frac{A}{\pi \times D_{o} \times l}$

where $N$ is the number of tubes, $A$ is the area of the heat transfer area $\left(\mathrm{m}^{2}\right), \pi$ worth $3.14, D_{o}$ tube diameter $(\mathrm{m})$, and $l$ is tube diameter $(\mathrm{m})$.

\section{RESULTS AND DISCUSSION}

In designing a shell and tube type heat exchanger, several assumption data are used for the calculation process of the heat exchanger design specifications, including the assumption data of the heat exchanger specifications and the assumption data of the fluid properties that work on the heat exchanger apparatus. Table 1 shows the assumptions for the dimensional specifications of the shell and tube type heat exchanger and Table 2 shows the assumptions for the fluid properties acting on the apparatus.

Table 1 Shell and Tube Type Heat Exchanger Specifications

\begin{tabular}{|c|c|}
\hline Material & Carbon Steel \\
\hline Length (m) & 6.096 \\
\hline Shell Diameter (m) & 0.154 \\
\hline Inner Tube Diameter (m) & 0.01483 \\
\hline Outer Tube Diameter (m) & 0.019 \\
\hline Wall Thickness (m) & 0.0017 \\
\hline Flow Area per Tube $\left(\mathrm{m}^{2}\right)$ & 0.00017 \\
\hline Tube layout angel $\left(^{\circ}\right)$ & 30 \\
\hline Thermal Conductivity $\left(\mathrm{W} / \mathrm{m}^{\circ} \mathrm{C}\right)$ & 45 \\
\hline
\end{tabular}


Table 2 Data of Fluid Properties of Working on Heat Exchanger

\begin{tabular}{|l|l|l|}
\hline Side & Shell Side & Tube Side \\
\hline Fluida Type & Hot Water $\left(\mathbf{T}_{\mathbf{h}}\right)$ & Cold Water $\left(\mathbf{T}_{\mathbf{c}}\right)$ \\
\hline Iinlet Temperature, $\mathbf{T}_{\text {in }}\left({ }^{\circ} \mathbf{C}\right)$ & 90 & 20 \\
\hline Ooutlet Temperature, $\mathbf{T}_{\text {out }}\left({ }^{\circ} \mathbf{C}\right)$ & 75 & 60 \\
\hline Fluid Flow Rate, $\mathbf{~ m}(\mathbf{k g} / \mathbf{s})$ & 0.303 & 0.606 \\
\hline Pressure, $\mathbf{P}(\mathbf{a t m})$ & 1 & 1 \\
\hline Heat Capacity, $\mathbf{C}_{\mathbf{p}}\left(\mathbf{J} / \mathbf{k g}^{\circ} \mathbf{C}\right)$ & 4206 & 4182 \\
\hline Density, $\boldsymbol{\rho}\left(\mathbf{k g} / \mathbf{m}^{\mathbf{3}}\right)$ & 1000 & 1000 \\
\hline Thermal Conductivity $(\mathbf{W} / \mathbf{m . K})$ & 0.6804 & 0.5978 \\
\hline
\end{tabular}

The present heat exchanger model is used to determine the thermal load $(Q)$, the logarithmic mean temperature difference $(L M T D)$, the heat transfer surface area $(A)$, and the number of tubes $(N t)$ of the heat exchanger. Data used to model the heat exchanger in the form of parameters whose values have been set as in Tables 1 and 2. Based on the analysis of the assumption data calculation, the designed heat exchanger follows the specifications in Table 3. Based on the shell and tube, the dimensions specifications which refer to the standards of The Tubular Exchanger Manufacturers Association (TEMA) and calculations, the 2D tube layout, 3D bundle layout, exchanger drawing, setting plan, and 3D exchanger drawing of the designed heat exchanger apparatus are shown in Figures 2-4.

The results of the heat exchanger that has been designed are two pass-shell and tube types. The heat transfer rate generated by the apparatus is $101.371 \mathrm{~W}$ (see Table 6). Other parameters such as LMTD, surface area, number of tubes, and effectiveness value of the designed heat exchanger are $37.70^{\circ} \mathrm{C}, 2.8392 \mathrm{~m}^{2}, 16 \mathrm{pcs}$, and $57.143 \%$, sequentially (see Table 6). Based on the calculation results, the shell and tube type heat exchanger which has been successfully designed with a heat transfer effectiveness greater than $50 \%$ with the characteristics of the flow in the shell and tube is turbulent flow type since the Reynolds number > 2300 (Hasanpour et al., 2014). One of the factors that affect the value of effectiveness in the heat exchanger is the LMTD value because the value of effectiveness 
measures the amount of heat carried. A high value of effectiveness associates with a hightemperature difference between input and output (Pourhoseini et al., 2018). However, based on the fouling factor value, the dimensions of the heat exchanger apparatus designed do not meet the requirements of the standard that has been set because the standard permissible dirt factor from TEMA for water fluid is $0.0002{ }^{\circ} \mathrm{C} \cdot \mathrm{m}^{2} / \mathrm{W}$.

Tabel 3 Heat Exchanger Specifications based on the Calculation Results

\begin{tabular}{|c|c|c|}
\hline No & Parameters & Results \\
\hline 1 & Initial Heat Transfer Rate $(Q)$ & $101.371 \mathrm{~W}$ \\
\hline 2 & $\begin{array}{l}\text { Logarithmic Mean Temperature Difference } \\
(L M T D)\end{array}$ & $35.70^{\circ} \mathrm{C}$ \\
\hline 3 & $\begin{array}{l}\text { Assumed Overall Fluid Heat Coefficient of } \\
\text { Water }\left(U_{a}\right)\end{array}$ & $1000 \mathrm{~W} / \mathrm{m}^{2} . \mathrm{K}$ \\
\hline 4 & Area of Heat Transfer $(A)$ & $2.8392 \mathrm{~m}^{2}$ \\
\hline 5 & Number of Tube $(\mathrm{Nt})$ & 16 \\
\hline 6 & CTP & 0.9 \\
\hline 7 & CL & 0.87 \\
\hline 8 & Total Heat Transfer Surface Area in Tube $\left(a_{t}\right)$ & $0.0006635 \mathrm{~m}^{2}$ \\
\hline 9 & Mass Flow Rate of Water Fluid in Tube $(G t)$ & $913.233 \mathrm{~kg} / \mathrm{m}^{2} . \mathrm{s}$ \\
\hline 10 & Reynold Number in Tube $(\operatorname{Re}, t)$ & 17299.53 \\
\hline 11 & Prandtl Number in Tube $(P r, t)$ & 2.6489 \\
\hline 12 & Nusselt Number in Tube $(\mathrm{Nu}, \mathrm{t})$ & 110.7030 \\
\hline 13 & $\begin{array}{l}\text { Convection Heat Transfer Coefficient in the } \\
\text { Tube }\left(h_{i}\right)\end{array}$ & $\begin{array}{l}3483.0690 \\
\mathrm{~W} / \mathrm{m}^{2} . \mathrm{K}\end{array}$ \\
\hline 14 & Bundle Shell $(\mathrm{Db})$ & $0.269 \mathrm{~m}$ \\
\hline 15 & Total Heat Transfer Surface Area in Shell $\left(a_{s}\right)$ & $0.0409 \mathrm{~m}^{2}$ \\
\hline 16 & Mass Flow Rate of Water Fluid in Shell $(G s)$ & $7.397 \mathrm{~kg} / \mathrm{m}^{2} . \mathrm{s}$ \\
\hline 17 & Equivalent Diameter $(\mathrm{De})$ & $0.343 \mathrm{~m}$ \\
\hline 18 & Reynold Number in Shell $(R e, t)$ & 8061.7676 \\
\hline 19 & Prandtl Number in Shell $(P r, t)$ & 1.3954 \\
\hline 20 & Nusselt Number in Shell $(\mathrm{Nu}, \mathrm{t})$ & 56.6682 \\
\hline 21 & $\begin{array}{l}\text { Convection Heat Transfer Coefficient in Shell } \\
\left(h_{o}\right)\end{array}$ & $112.3195 \mathrm{~W} / \mathrm{m}^{2} . \mathrm{K}$ \\
\hline 22 & $\begin{array}{l}\text { Overall Heat Transfer Coefficient Actual } \\
\left(U_{a c t}\right)\end{array}$ & $108.811 \mathrm{~W} / \mathrm{m}^{2} . \mathrm{K}$ \\
\hline 23 & Hot Fluid Heat Capacity Rate $\left(C_{h}\right)$ & $1274.418 \mathrm{~W} /{ }^{\circ} \mathrm{C}$ \\
\hline 24 & Cold Fluid Heat Capacity Rate $\left(C_{c}\right)$ & $2534.292 \mathrm{~W} /{ }^{\circ} \mathrm{C}$ \\
\hline 25 & HE Effectiveness $(\varepsilon)$ & $57.143 \%$ \\
\hline 26 & Number of Transfer Unit $(N T U)$ & 0.122 \\
\hline 27 & Dirt Factor $(D f)$ & $0.008^{\circ} \mathrm{C} . \mathrm{m}^{2} / \mathrm{W}$ \\
\hline
\end{tabular}


Although the effectiveness of the heat exchanger is more than $50 \%$, however, this heat exchanger still does not meet the standards when viewed from the point of view of the fouling factor value. Fouling occurs due to the formation of a layered deposit on the heat transfer surface of an unwanted substance or compound. Deposit on the surface of the heat exchanger gives rise to lower efficiency heat transfer. Based on Jurnal (2018) and Costa et al. (2013), several factors cause the fouling factor value to be very high including the diameter shell, diameter tube, number of the baffle, type of fluid, fluid temperature, mass flow rate, the type and concentration of impurities present in the fluid. Therefore, the variables that affect the fouling factor need to be considered to obtain a fouling factor that is minimal.

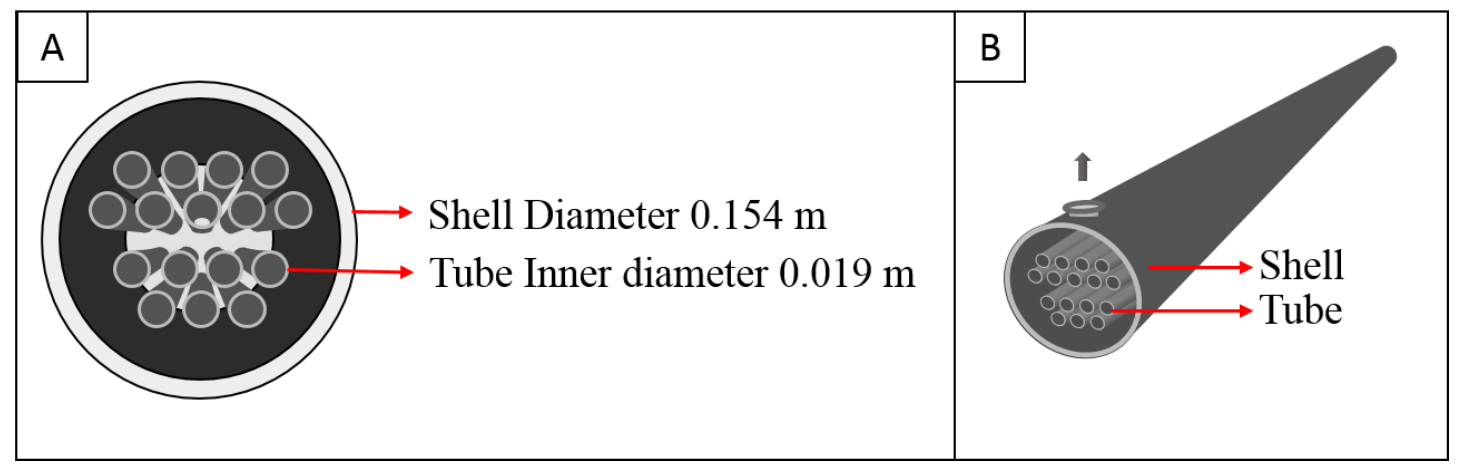

FIGURE 2 2D tube layout (a) and 3D bundle layout (b)

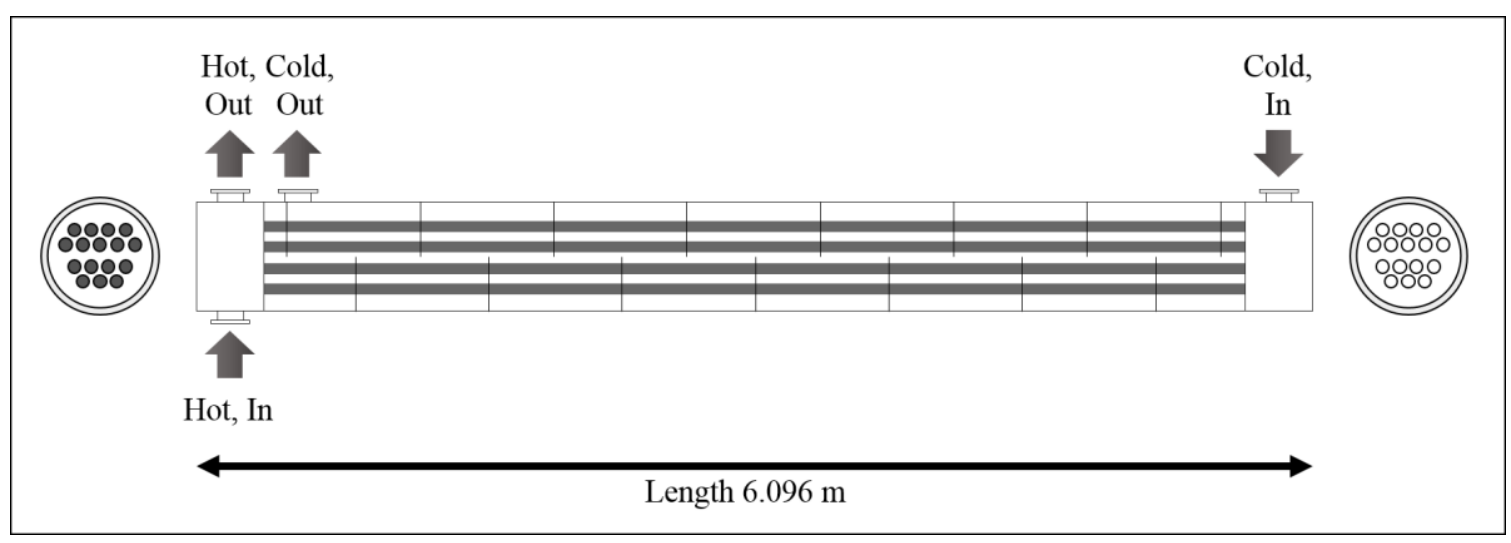

FIGURE 3 Exchanger drawing 


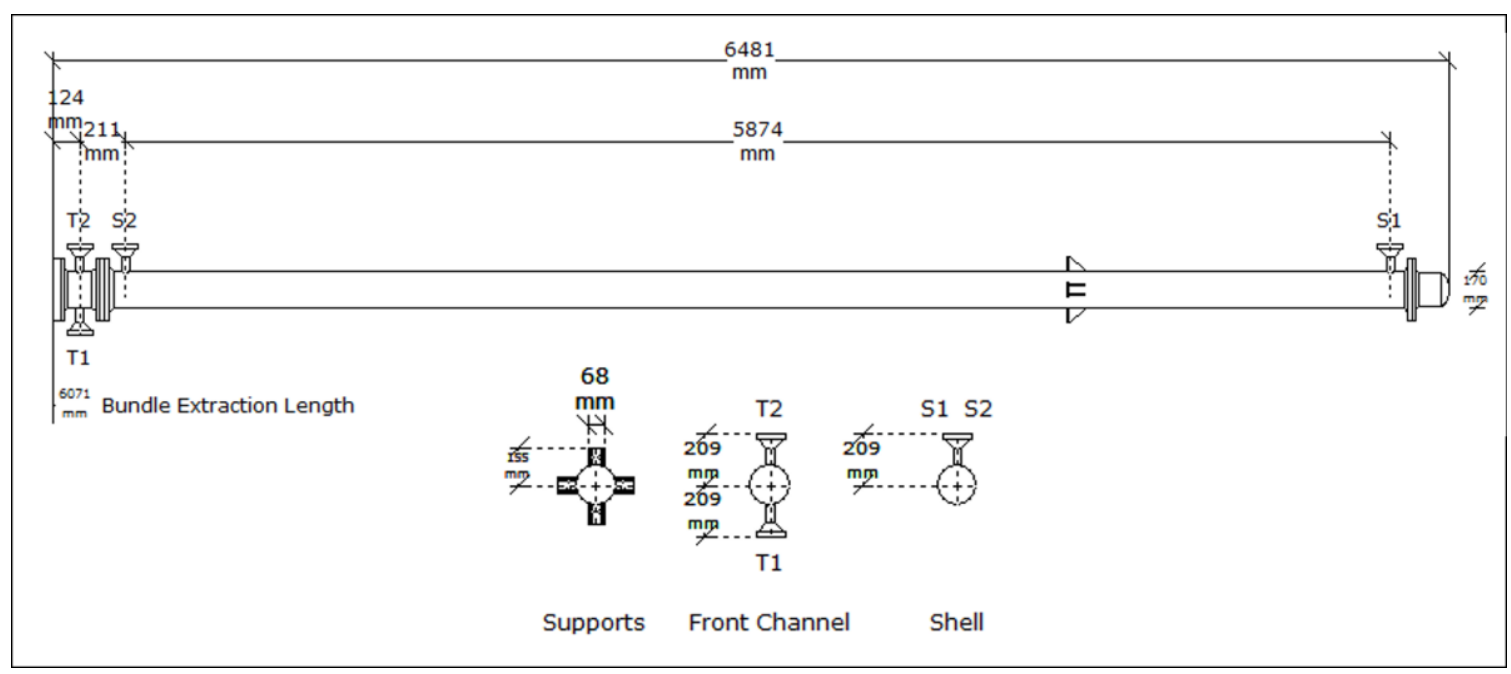

FIGURE 4 Setting plan

\section{CONCLUSION}

The results of this study indicate that in designing shell and tube type heat exchanger with a capacity of 101371 Watt obtained shell and tube with two passes type, equipped with the number of tubes as much as 16 pieces. We get the convection heat transfer coefficient for shell and tube are 3483 and $112 \mathrm{~W} / \mathrm{m}^{2} . \mathrm{K}$, respectively. The effectiveness value of the designed heat exchanger is equal to $57 \%$.

\section{ACKNOWLEDGEMENT}

We would like to thank Universitas Pendidikan Indonesia for supporting this study. We acknowledged RISTEK BRIN (Grant: Penelitian Terapan Unggulan Perguruan Tinggi) and Bangdos Universitas Pendidikan Indonesia.

\section{REFERENCES}

Araiz, M., Casi, Á., Catalán, L., Martínez, Á. \& Astrain, D. 2020. Prospects of waste-heat recovery from a real industry using thermoelectric generators: Economic and power output analysis. Energy Conversion and Management. 205: 112376.

Chen, J., Liu, Y., Lu, X., Ji, X. \& Wang, C. 2019. Designing heat exchanger for enhancing heat transfer of slurries in biogas plants. Energy Procedia. 158: 1288-1293. 
Costa, A. L. H., Tavares, V. B. G., Borges, J. L., Queiroz, E. M., Pessoa, F. L. P., Liporace, F. D. S. \& de Oliveira, S. G. 2013. Parameter estimation of fouling models in crude preheat trains. Heat transfer engineering. 34(8-9): 683-691.

Dekhil, M. A., Tala, J. V. S., Bulliard-Sauret, O. \& Bougeard, D. 2020. Development of an innovative heat exchanger for sensible heat storage in agro-food industry. Applied Thermal Engineering. 177: 115412.

Delpech, B., Milani, M., Montorsi, L., Boscardin, D., Chauhan, A., Almahmoud, S. \& Jouhara, H. 2018. Energy efficiency enhancement and waste heat recovery in industrial processes by means of the heat pipe technology: Case of the ceramic industry. Energy. 158: 656-665.

Hasanpour, A., Farhadi, M., \& Sedighi, K. 2014. A review study on twisted tape inserts on turbulent flow heat exchangers: The overall enhancement ratio criteria. International Communications In Heat and Mass Transfer. 55: 53-62.

Ihsan, S. 2017. Perencanaan dan analisa perhitungan jumlah tube dan diameter shell pada kondensor berpendingin air pada sistem refrigerasi $\mathrm{NH}_{3}$. Jurnal Teknologi Proses dan Inovasi Indonesia. 2(1): 14-15.

Jurnal, R. T. 2018. Pengaruh Fouling terhadap Laju Perpindahan Panas pada Superheater Boiler Cfb Pltu Sebalang. Jurnal Powerplant, 6(1), 48-57.

Nurahmadi, A. 2017. Kajian Alat Penukar Kalor Shell And Tube Menggunakan Program Heat Transfer Research Inc (Htri). Barometer. 2(1): 12-18.

Nandiyanto, A. B. D.; Andika, R.; Aziz, M. \& Riza, L. S. 2018. Working volume and milling time on the product size/morphology, product yield, and electricity consumption in the ball-milling process of organic material. Indonesian Journal of Science and Technology, 3(2), 82-94.

Pourhoseini, S. H., Naghizadeh, N. \& Hoseinzadeh, H. 2018. Effect of silver-water 
nanofluid on heat transfer performance of a plate heat exchanger: An experimental and theoretical study. Powder Technology, 332, 279-286.

Shahsavar, A., Majidzadeh, A. H., Mahani, R. B. \& Talebizadehsardari, P. 2021. Entropy and thermal performance analysis of PCM melting and solidification mechanisms in a wavy channel triplex-tube HE. Renewable Energy. 165: 52-72.

Sukmafitri, A.; Ragadhita, R. \& Nandiyanto, A. B. D. 2020. Disk rotation speed and diameter of impactor in disk mill on particle size distribution from rice husk. Journal of Engineering Science and Technology, 15(3), 1698-1704. 